\title{
The Turkish Validity and Reliability of The Physical Activity Self-efficacy Scale For Children
}

\section{Çocuklar İçin Fiziksel Aktivite Öz Yeterlik Ölçeği Türkçe Geçerlik ve Güvenirliği}

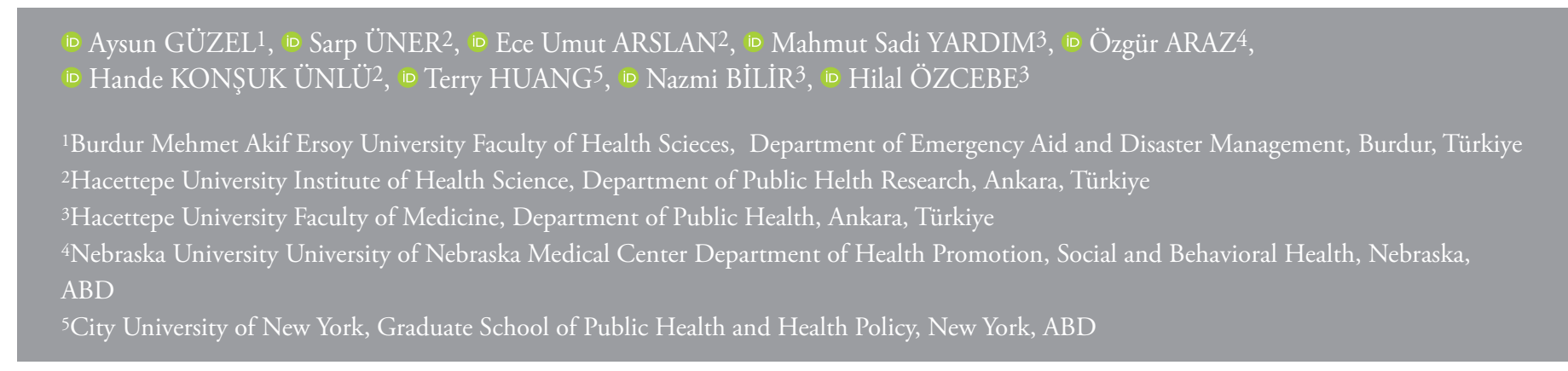

\section{ABSTRACT}

Objective: Purpose of this study is to determine validity and reliability of the Physical Activity Self-efficacy scale for Turkish children (PASSC).

Methods: The study was conducted as a methodological epidemiological study in the province of Ankara. The study aimed to reach all fourth grades (9-11 years) in the selected six schools $(n=641)$. Six hundred and seven students participated in the first stage of the study and 499 students in the second (test-retest) which was carried out two weeks later. In the study, personal information form and data collection tool including PASSC were used. The data were analyzed using SPSS 18 and AMOS programmes.

Results: Among the children who participated in the first stage of the study; $53.0 \%$ were male and $36.2 \%$ were from schools with low socioeconomic level . Results from the confirmatory factor analysis for boys showed: $\mathrm{p}<0.001, \chi^{2} / \mathrm{sd}=2.6$, RMSEA $=0.07$ and GFI $=0.95$, and for girls: $\mathrm{p}<0.001, \chi^{2} / \mathrm{SD}=2.4$, RMSEA $=0.07$ and GFI $=0.95$. The Cronbach's alpha value was determined as 0.84 for boys and 0.81 for girls in the validity and reliability analyzes for the PASSC. The analyzes which were performed for boys and girls seperately led to a model consisting of a single factor with no modification requirement.

\section{ÖZ}

Amaç: Bu araştırmanın amacı Çocuklar için Fiziksel Aktivite Öz Yeterlik ölçeğinin (Ç-FAÖY) Türkçe geçerlik ve güvenirliğini belirlemektir.

Yöntemler: Araştırma metodolojik tipte epidemiyolojik bir araştırmadır ve Ankara ilinde yapılmıştır. Araştırmada örneklem seçilmemiş altı okulda ki tüm dördüncü sınıflara (9-11 yaş) ulaşılması hedeflenmiştir ( $\mathrm{n}=641)$. Araştırmanın ilk aşamasına 607 öğrenci, iki hafta sonra gerçekleştirilen ikinci (test-tekrar test) aşamasına 499 öğrenci katılmıştır. Araştırmada, kişisel bilgi formu ve Ç-FAÖY ölçeğini içeren veri toplama aracı kullanılmıştır. Verilerin analizinde SPSS 18 ve AMOS programları kullanılmıştır.

Bulgular: Çalışmanın ilk aşamasına katılan çocukların \%53,0'1 erkektir ve \%36,2'si düşük gelir grubundadır. Ç-FAÖY ile ilgili erkek çocuklar için yapılan doğrulayıcı faktör analizinde $\mathrm{p}<0,001$, $\chi^{2} / \mathrm{SD}=2,6$, RMSEA=0,07 ve GFI=0,95; kız çocuklar için yapılan doğrulayıcı faktör analizinde $\mathrm{p}<0,001, \chi^{2} / \mathrm{sd}=2,4$, RMSEA $=0,07$ ve $\mathrm{GFI}=0,95$ olarak bulunmuştur. Ç-FAÖY geçerlik ve güvenirlik analizlerinde, Cronbach alfa değeri erkek çocuklar için 0,84; kız çocuklar için 0,81 olarak saptanmıştır. Erkek ve kız çocuklar için ayrı ayrı yapılan analizler sonucunda tek faktörden oluşan ve modifikasyona gerek duyulmayan bir model oluşmuştur.
Address for Correspondence: Aysun GÜZEL, Burdur Mehmet Akif Ersoy University Faculty of Health Scieces, Department of Emergency Aid and Disaster Management, Burdur, Türkiye E-mail: ayurdakul@mehmetakif.edu.tr ORCID ID: orcid.org/0000-0002-7071-3511
Received: 13.09 .2019

Accepted: 17.12.2019

Cite this article as: Güzel A, Üner S, Arslan Eu, Yardım Ms, Araz Ö, Konşuk Ünlü H, Huang T, Bilir N, Özcebe $\mathrm{H}$. The Turkish Validity and Reliability of The Physical Activity Self-efficacy Scale For Children.

Bezmialem Science 2020;8(4):363-370. 
Conclusion: The PASSC which was adapted into Turkish for boys and girls was a valid and reliable assessment tool.

Keywords: Child, Physical activity, Self-efficacy, validity, reliability.
Sonuç: Erkek ve kız çocuklar için ayrı ayrı Türkçe uyarlaması yapılan Ç-FAÖY geçerli ve güvenilir bir ölçme aracıdır.

Anahtar Sözcükler: Çocuk, fiziksel aktivite, öz yeterlik, geçerlik, güvenirlik.

\section{Introduction}

Regular physical activity has an effect on the protection and improvement of the health of both the individual and the society (1). Physical activity reduces smoking (1), depression (2), cardiovascular diseases, some types of cancer, stroke, diabetes and obesity, prolongs the life expectancy and ensures a healthy life (3).

While physical activity in childhood ensures the development of muscles, the development of psychosocial behavior positively and the increase of self-esteem (4), it reduces the occurrence of cardiovascular diseases, hypertension and obesity, and prevents sedentary lifestyle (passive activities such as watching television and computer) (5). The behaviors of individuals who start physical activity in childhood change over time, and their desire for physical activity becomes permanent $(3,6)$.

Self-efficacy associated with physical activity is an important concept that determines attitudes and behaviors such as how a person sees his/her own capacity, what activities he/she will choose and how much effort he/she will spend for these activities, and how long he/she will continue to do physical activity when faced with failure (7). Understanding the characteristics of childhood period, encouraging children to physical activity by examining children's knowledge, abilities and attitudes, and ensuring the sustainability of this situation are possible by improving children's self-efficacy (3). Self-efficacy, which is among the determinants of human behavior, refers to the belief that the individual can successfully perform the behaviors that enable him/her to achieve the desired results (regulatory activity) and his/her belief in his/ her own ability in a specific area (task activity) $(8,9)$. Self-efficacy associated with one's belief, cognitive process, motor activities and physical performance is both the result and an important determinant of physical activity. While regular physical activity contributes to the formation of self-efficacy, it also creates a desire for regular physical activity (by increasing the number and frequency of physical activity) in time (10). Being successful and increasing self-confidence create a change in behavior towards increasing physical activity self-efficacy (11). In particular, while active and regular physical activity in children increases the child's physical activity self-efficacy (10), inadequate physical activity reduces the child's sense of confidence and negatively affects the child's and the community's health (12).

The goals set by the child directed to physical activity increase his motor development and confidence in his own skills over time (13). Planning activities involving moderate or severe levels of physical activity in primary school-age children-considering the age and gender of the child- increases children's orientation to physical activity, and the most important predictor of this situation is the perceived physical activity self-efficacy (6). Perceived physical activity self-efficacy is affected by personal characteristics such as the child's age, gender (biological factors), as well as the child's access to the gym or ability to do physical activity at school, the ability to access the materials required for physical activity, the ability to allocate time for physical activity, and environmental factors such as peers, parents and teachers (14). Children's physical activity self-efficacy, a concept that is affected by individual and environmental factors and can change, increases especially with the encouragement of parents or teachers (6). The development or adaptation of measurement tools for determining physical activity self-efficacy is important for planning intervention studies for physical activity behaviors and maintaining a long and quality life (15). The studies conducted in our country were the Physical Activity Questionnare for children which was adapted to Turkish by Tanır (16) for the eighth grade students, and the Physical Activity Questionnaire for primary school students which was adapted to Turkish by Emlek Sert and Bayık Temel (17) for the sixth, seventh and eighth grade students. The biggest difference between the Physical Activity Self-efficacy Scale for Turkish Children (PASSC) and these scales is that PASSC is designed for (young) children in the 9-11 age group. The Physical Activity Questionnare for children is intended to recall the activities performed in the last 7 days and gives an idea about the general physical activity habits of the participants and does not contain information about the estimated calorie expenditure, frequency, intensity and duration of the activity (16). The Physical Activity Questionnaire for primary school students questions the status of performing any of the activities (hopscotch, football, basketball, gymnastics, etc.) stated in the questions in the last seven days, the level of participation in physical education lessons, activities performed during breaks, lunch time, after school, in the evening and weekends and the frequency of these activities, the frequency of leisure activities in the last seven days, and the frequency of sports, games, dance and other physical activities for seven days a week. This scale consists of 9 items and the first item includes 21 activities, therefore it is comprehensive and detailed (17). PASSC is a scale consisting of 9 items, easy to answer, without sub-activities or dimensions, and questioning the self-efficacy of the person towards physical activity. No other physical activity scale developed or adapted to Turkish in our country for children studying in the fourth grade or below, has not been found in the literature.

The validity and reliability study of PASSC was included in the first step of a project. The use of scales other than PASSC in the project and the fact that each of the scales used had a certain age range caused the data collection tool to be long. Since the data 
collection tool was long, the age range was planned according to all scales and the project was planned to be carried out in primary schools. Children between the ages of 9-11 were included in the validity and reliability study of the PASSC.

The aim of this study was to perform Turkish adaptation of the PASSC, which was developed by Saunders et al. (18) and modified by Sherwood et al. (19), in boys and girls separately to evaluate the physical activity self-efficacy.

\section{Method}

The validity and reliability study of the Turkish form of PASSC was conducted in six schools selected from three different socioeconomic levels in Ankara. Socioeconomic level determinants based on income, education and occupation are frequently used in determining the socioeconomic level. Since it is not possible to use these determinants directly for children; in studies on children, determining the socioeconomic level is preferred at the family, community and school levels (20). In determining the socioeconomic level of this study, socioeconomic determinants and classification developed by Yüceşahin and Tuysuz were used (21). For school level socioeconomic classification, all metropolitan districts were listed according to their socioeconomic levels, and all private schools constituted the sample for the high income level. At the top of the list, the state schools in Çankaya and Yenimahalle districts constituted the sample for the middle-income stratum, and at the bottom of the list, the state schools in the Altındağ, Mamak and Sincan districts constituted the sample for low-income stratum. In the study, it was aimed to reach all fourth grades (9-11 years) in six schools, among schools selected according to their socioeconomic level, in which sample was not re-selected from $(n=641)$. Six hundred and seven students who were at the school during the data collection period and agreed to participate in the study constituted the sample of the study. The data collection phase of the epidemiological study planned as a methodological type consisted of two parts. Six hundred and seven students (94.7\%) participated in the first stage of the study and 499 students $(77.8 \%)$ participated in the second stage (test-retest), which was carried out two weeks later.

The inclusion criteria were defined as being between the ages of 9 and 11 , being able to understand the questions and express own opinions and agree to participate in the study.

The data collection tool of the study consisted of a personal information form consisting of 5 questions including some sociodemographic information and a PASSC form. PASSC was developed by Saunders et al. (18). There were three subdimensions in its original form. Sherwood et al.(19) modified the scale and transformed it into nine items and a one-dimensional structure in 2004. We used its final form modified by Sherwood et al. While the original form of the scale was being developed, girls in the 8-10 age group were included in the study group, the Turkish adaptation study was conducted for both girls and boys. The validity and reliability study of this scale was included in the first step of a project. Due to the fact that there were other scales used in the project and all scales used were analyzed for both boys and girls, the validity and reliability of the scale was also made for boys. The scoring of the scale is made by reading the items in the scale and giving 1 point to the "not difficult" option, 2 points to the "somewhat difficult" option, and 3 points to the "very difficult" option. Scale total score is calculated by adding the scores obtained from all items. There are no reverse coded items in the scale, the lowest score that can be obtained from the scale is 9 and the highest score is 27 . High scores from the scale indicate the strength of self-efficacy for physical activity. The Turkish Form of PASSC is attached at the end of the article.

The data collection phase was conducted between April 5 and May 18, 2015. The data collection form was distributed to the students by researchers and teachers at the same time, and it took students about 20-25 minutes to fill out the form.

\section{Statistical Analysis}

The validity and reliability analyzes of the PASSC were made by using SPSS 18 and AMOS programs in the study. Content validity, face validity and construct validity were used for validity analysis. Internal consistency and test-retest method were used for reliability analysis. In construct validity, the minimum value was determined as 0.30 for exploratory factor analysis (22), $\chi^{2 /}$ $\mathrm{df}<3$; RMSEA <0.08; GFI $>0.90$ were determined as acceptable values in the model fit statistics of confirmatory factor analysis (23), $\alpha>0.70$ was determined as Cronbach alpha value (24), and reliability value for test-retest phase was determined between -1 and +1 (25). In the scope/content validity of the research, the language equivalence of the PASSC, which was valid for both boys and girls, was provided first. First of all, the scale was translated into Turkish by researchers who knew Turkish and English at a good level. The expert panel consisting of experienced people (public health experts, other health professionals, Turkish teachers and Turkish Language and Literature experts) gave their opinions on Turkish translation and tried to ensure conformity in terms of trans-cultural meaning. The Turkish version of the scale was rearranged by making corrections suggested by the expert panel. A pre-application was made with 20 children from the age group in which the study would be conducted and their families, and the Turkish equivalence of the scale was completed. The scale, of whichTurkish equivalence was completed, was evaluated by a team of five Turkish teachers, and experts in Turkish language and literature in terms of language validity. The team gave the form its final form. The scale, which was translated into Turkish, was translated back into English by a professional Translation and Interpretation Office in the USA (United States of America). A group of native English speakers examined the scale, which was translated back into English, to determine its similarity with its original form.

The readability, understandability, applicability of the scale, cultural characteristics and value judgments of the society in which the scale would be applied were examined in order to ensure the face validity of the PASSC. Public health experts and other health professionals evaluated the items in the scale. 
The adaptation of the scale was made in 2015 within the scope of the project named "Childhood Obesity, Perception and Approach of Families” (Project No: TUA-2015-5521). In order to conduct the study approved by the Hacettepe University NonInvasive Ethics Committee (GO 14-429-07), written permission was obtained from the Provincial Directorate of National Education, school administration and students' families, and verbal permission was obtained from the students.

\section{Results}

Some characteristics of the children participating in the first and second parts of the study are given in Table 1.

Of the children participating in the first part of the study, $53.0 \%$ were male and $36.2 \%$ were in the low income group. Of the children participating in the second part of the study (test-retest stage), $52.7 \%$ were male and $36.3 \%$ were in the middle income group (Table 1).

\section{Validity Analysis}

\section{Content and Face Validity}

The scope/content validity of the study was examined by experts and the translated text was found to be compatible with the original text.
As a result of the face validity of the research, it was decided to keep the scale in its original form, to use it after language correction and to analyze.

\section{Construct Validity}

\section{Exploratory factor analysis}

The values of the scale in boys and girls obtained as a result of the principal component analysis are presented in Table 2.

In the exploratory factor analysis of PASSC in boys, the KaiserMeyer-Olkin (KMO) value was found to be 0.78 and the sample size was good (Table 2). Item factor loading was found as minimum 0.42 and maximum 0.62 , both of which were above the critical value of 0.30 . It was determined that PASSC had a one-dimensional structure that explained $30.913 \%$ of the total variance for boys and had an eigenvalue of $2.78 \%$.

In the exploratory factor analysis of PASSC in girls, the (KMO) value was found to be 0.80 and the sample size was very good (Table 2). Item factor loading was found as minimum 0.47 and maximum 0.66 , both of which were above the critical value of 0.30. It was determined that PASSC had a one-dimensional structure that explained $33.363 \%$ of the total variance for girls and had an eigenvalue of $3.00 \%$.

Table 1. Some characteristics of boys and girls participating in the study

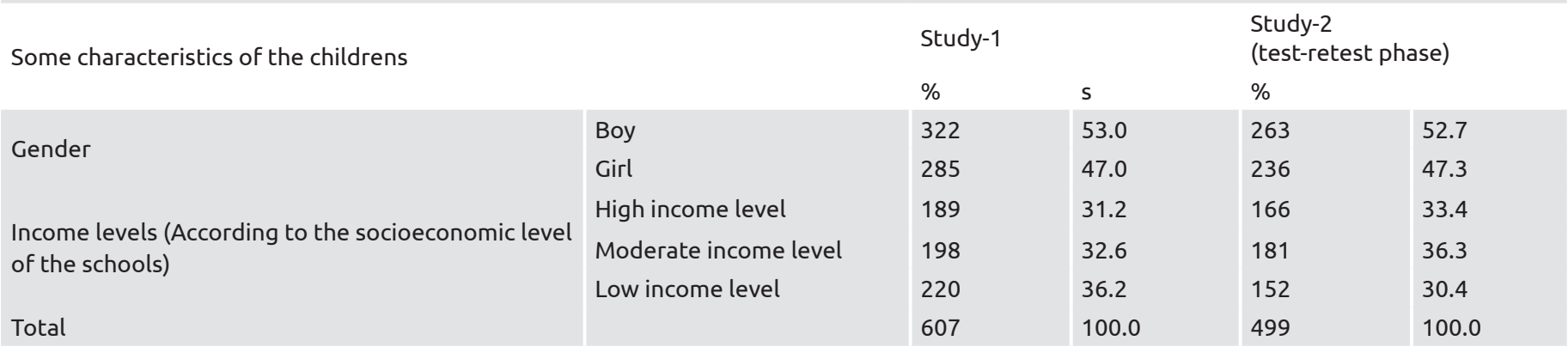

Table 2. Values of basic component analysis in physical activity self-efficacy scale for boys and girls

Items

1. Being physically active instead of watching TV

2. Being physically active after school most days of the week

3. Asking my family or other elders to do things that require physical activity with me

4. Asking my family or other elders to take me to physical activity or sports

5. Asking my friends to do physical activity with me.

6. Being physically active on weekends (saturday and sunday)

7. Playing in sports teams

8. Being physically active at home

9. Being physically active even when tired

Eigenvalue

Described variance (\%)

Cumulative variance (\%)

Kaiser-Meyer-Olkin (KMO) test

Bartlett test

${ }^{1}$ Explanatory factor analysis was done.

\begin{tabular}{|l|l|}
\hline Boy ${ }^{1}$ & Girl1 \\
\hline 0.52 & 0.53 \\
0.62 & 0.61 \\
0.58 & 0.54 \\
0.56 & 0.66 \\
0.49 & 0.50 \\
0.62 & 0.47 \\
0.42 & 0.52 \\
0.58 & 0.64 \\
0.53 & 0.65 \\
2.782 & 3.003 \\
30.913 & 33.363 \\
30.913 & 33.363 \\
0.788 & 0.801 \\
$392.08(p<0.001)$ & $413.07(p<0.001)$ \\
\hline
\end{tabular}




\section{Confirmatory factor analysis}

The results of the confirmatory factor analysis of the PASSC for boys and girls are presented in Figure 1.

In the confirmatory factor analysis of PASSC for boys; $\mathrm{p}<0.001$, $\chi^{2} / \mathrm{df}=2.6$, RMSEA $=0.07$ and GFI $=0.95$ (Figure 1). The singlefactor model reached acceptable values and acceptable fit in the fit statistics. This model did not require modification. The factor loading values of the scale items varied between 0.33 and 0.56 , and all load values were statistically significant $(\mathrm{p}<0.001)$.

In the confirmatory factor analysis of PASSC for girls; $\mathrm{p}<0.001$, $\chi^{2} / \mathrm{df}=2.4$, RMSEA $=0.07$ and GFI $=0.95$ (Figure 1). The single-factor model reached acceptable values and acceptable fit in the fit statistics. This model did not require modification. The factor loading values of the scale items vary between 0.39 and 0.60 , and all load values were statistically significant $(\mathrm{p}<0.001)$.

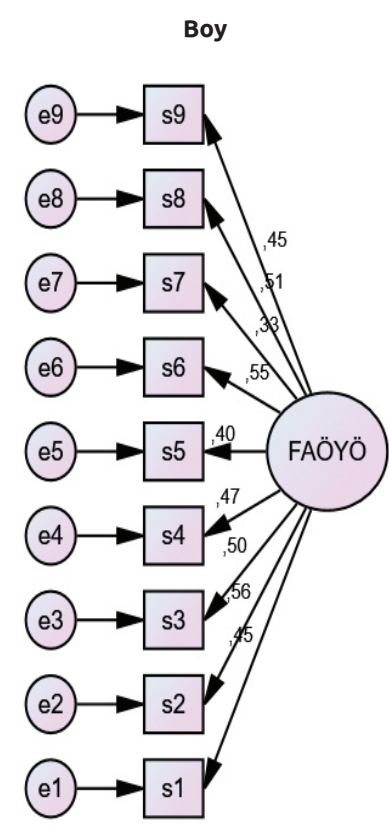

RMSEA: 0.071 (Pclose $=0.039)$, CMIN/df: 2.640 ( $p<0.001)$, GFI: 0.950

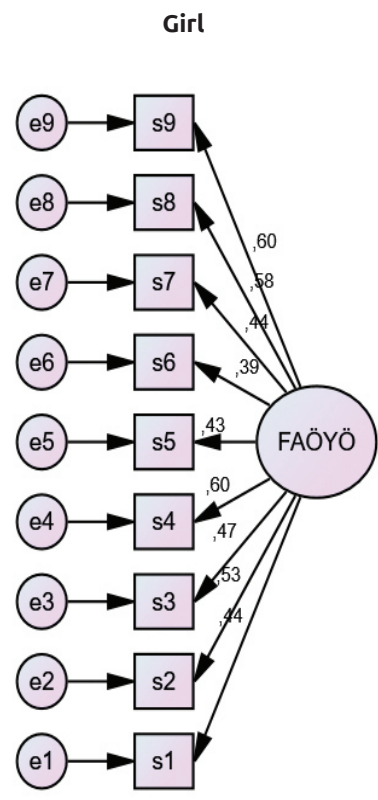

RMSEA: 0.071 (Pclose $=0.051)$ CMIN/df: 2.443 ( $p<0.001)$ GFI: 0.951

Figure 1. Confirmatory factor analysis results of the physical activity self-efficacy scale for boys and girls

\section{Reliability Analysis}

\section{Internal Consistency (Cronbach alpha)}

Cronbach's alpha value of PASSC was 0.84 for boys and 0.81 for girls.

\section{Test-Retest Method}

In boys, there was a significant, strong and positive correlation between the first round PASSC and the second round PASSC $(\mathrm{p}<0.01 ; \mathrm{r}: 0.73)$; and in girls, there was a significant, strong and positive correlation $(\mathrm{p}<0.01 ; \mathrm{r}: 0.75)$ between the first round PASSC and the second round PASSC.

There was no statistically significant difference between the genders of the boys and girls participating in the study and the mean PASSC ( $p>0.05)$. There was no statistically significant difference between the socioeconomic level of the school where the boys and girls participating in the study and the mean PASSC (p>0.05) (Table 3).

\section{Discussion}

Studies conducted in our country have emphasized that physical activity self-efficacy studies involving children are limited (26, 27). In this study, it was aimed to adapt the PASSC to Turkish and to contribute to the qualitative and quantitative increase in future studies in this field. Adapting PASSC, increasing the number of researches to be conducted in this field, and determining children's self-efficacy in physical activity are important in order to determine the methods that can make children gain sports habits based on these self-competencies. Good mood, decrease in hunger and increase in food and fat burning (acceleration of metabolism) in children who do sports contribute to child health by increasing endurance and quality sleep (28).

The PASSC was developed by Saunders et al. (18) and modified by Sherwood et al. (19). In this study, the final version of PASSC which was modified by Sherwood et al. (19) and consisted of 9 items was used. Two hundred and ten African American girls participated in the original modified version of the scale. The study was conducted in four different states and the age, income and the education of their families constituted the sociodemographic variables of the study (19). In our study, 285 girls and 322 boys participated. In the literature, it was stated that it would be sufficient to reach 5 or 10 times the number of items in validity and reliability studies, and the number of

Table 3. The relationship between some characteristics of boys and girls participating in the study and the means of the physical activity self-efficacy scale for children

\begin{tabular}{|c|c|c|c|c|c|}
\hline \multicolumn{2}{|l|}{ Some characteristics of the children } & s & Mean \pm SD* & Median & Lowest/Highest \\
\hline \multirow{2}{*}{ Gender } & Boy & 322 & $12.7 \pm 3.0$ & 12.0 & $9.00 / 23.00$ \\
\hline & Girl & 285 & $12.7 \pm 3.1$ & 12.0 & $9.00 / 23.00$ \\
\hline \multirow{2}{*}{$\begin{array}{l}\text { Income levels (According to the } \\
\text { socioeconomic level of the schools) }\end{array}$} & Moderate income level & 198 & $12.4 \pm 3.0$ & 12.0 & $9.00 / 23.00$ \\
\hline & Low income level & 220 & $12.8 \pm 3.1$ & 12.0 & $9.00 / 23.00$ \\
\hline
\end{tabular}


individuals should be at least 300 (22). The sample size achieved in this study and in the original study were well above the value it should have been. In the original study, while the income levels of the families were directly asked to the children, in this study, instead of asking the children about the family income status directly, three socioeconomic levels were determined as low, medium and high at the beginning of the study as suggested in the literature $(20,21)$, and the study was conducted in six schools selected from these levels. Changes in children's eating habits due to the increase in the time spent in front of the computer, the products in the advertisements or other factors; decrease physical activity and it increase the frequency of obesity in our country's children (27). This situation directly affects both girls and boys. Therefore, in this study, it was important to adapt PASSC for both boys and girls and to use the scale for both genders. The authors of the original study explained that their study was conducted only with girls, as physical activity decreased more rapidly in adolescents compared to boys, and obesity in girls was a problem for public health (19). This study is the first step of a project. Due to the fact that there were other scales used in the project and all scales used were analyzed for both boys and girls, the validity and reliability of the scale were also made for boys.

In the literature, there are physical activity scales for children developed by some researchers or adapted to their own countries $(29,30,31,32)$. When the studies conducted in our country were examined, two physical activity scales, which were valid and reliable, were reached to measure the physical activity competence of children. The first of these is the Physical Activity Questionnare for older children developed by Crocker et al. (33). Its Turkish adaptation was made by Tanır (16) for the eighth grades. The second is that Physical Activity Questionnaire for primary school students developed by Kowalski et al. (34). Its Turkish adaptation study for our country was conducted by Emlek Sert and Bayık Temel for the sixth, seventh and eighth grades (17). A Physical Activity scale, which was developed or adapted to Turkish for fourth grade (9-11 years) or younger children in our country, was not found in the literature. In addition to age group, another feature that distinguishes PASSC from other scales is that it measures children's self-efficacy towards physical activity, not their state or frequency of physical activity. Therefore, the results of this study are very important in measuring the physical activity self-efficacy of young children.

In the validity analysis of this study, firstly, the findings regarding the content validity of PASSC were evaluated. In a study, it was emphasized that instead of creating measurement tools on various subjects separately for each country, translation and adaptation of the measurement tool from the original language was cheaper, time-saving and advantageous in terms of its use in international studies (35). In this study, no changes were made in the dimensions and scope defined in the original form of the scale in the content validity section, only language validity of the scale was made. Not every word in the expressions was translated and care was taken to preserve the integrity of the meaning. It was determined that there were sentences in the scale that did not fully reflect the content of the sub-dimension. In order to preserve the original form, the items of the scale were only regulated in terms of language, in a way to bear the meaning expressed.

Secondly, the face validity of the scale was evaluated in terms of validity. Studies have emphasized that the number of experts involved in face validity should be at least three $(36,37,38)$. The face validity assessment of the scale was made by four public health experts, two health professionals, and a total of four experts. In line with the opinions of the experts, language arrangements were made by preserving the meanings of the expressions.

Thirdly, in terms of validity, factor analysis of the scale was conducted. In the factor analysis performed in the original study of the PASSC, the item factor loading was found to be the lowest 0.34 and the highest 0.71 . As a result of the factor analysis performed in the original study, a one-dimensional structure that explained $28 \%$ of the total variance and had an eigenvalue of $2.53 \%$ emerged (19). In this study, when the results of boys and girls were evaluated together, item factor loading was found to be the lowest 0.42 and the highest 0.66 . The original study and the factor loading results obtained in this study were found to be above 0.30 , which was accepted as the limit in the literature (22). As a result of the factor analysis performed in this study, a one-dimensional structure (explaining 30\% and 33\% of the total variance, respectively) for boys and girls emerged. In the literature, there are resources stating that the variance rate in factor analysis should be at least $50 \%(22,39)$ or at least $60 \%(40)$. The total variance rates found in this study and the original study were found to be lower than the limit values in the literature.

Fourthly, in terms of validity, findings regarding the construct validity of the scale were evaluated. In the literature, there is no clear suggestion about which indices (except $\chi^{2} / \mathrm{df}$ ) used in construct validity should be $(23,41,42,43)$. In a study, it was stated that the index values that were important for determining the construct validity were RMSE, SRMR, CFI, GFI, NFI and NNFI (23). In the original form of the study, fit indices were not mentioned (19). When the results of this study were examined, it was found that the values obtained from the data of both boys and girls reached the acceptable values $\left(\chi^{2} / s d<3\right.$; RMSEA <0.08; GFI >0.90) required to provide fit statistics (23). No modification was required in both models and acceptable fit was achieved in the fit statistics.

In this study for the reliability analysis of the PASSC, internal consistency was determined first. The Cronbach alpha value of the PASSC in the original study was found to be 0.67 (19). In this study, the Cronbach alpha value of PASSC calculated separately for boys and girls was found to be significantly higher than both the limit value (24) and the original study. In the PASSC results obtained from this study, the values required for the acceptance of validity and reliability studies were reached.

In this study regarding the reliability analysis of the PASSC, secondly, test-retest phase was evaluated. The correlations obtained as a result of the PASSC test-retest phase were found 
to be significant, high and positive for both girls and boys. A moderate correlation was found in the test-retest phase of the PASSC's original study (19). The results obtained from our study were quite high and were compatible with the limit values in the literature (25). The results of this study and the original study were in agreement with each other.

\section{Study Limitations}

The research was a methodological study. It showed similar limitations with other methodological studies. The limitations of the study were that the adaptation study was carried out with a group living in Ankara, this group was selected by the researchers, the selected age group was only 9-11 years old, and the socioeconomic status was not measured individually.

\section{Conclusion}

The Turkish adaptation of PASSC, which was modified by Sherwood et al. (19), was found valid and reliable for boys and girls.

\section{Ethics}

Ethics Committee Approval: The study approved by the Hacettepe University Non-Invasive Ethics Committee (GO 14429-07)

Informed Consent: Written permission was obtained from the Provincial Directorate of National Education, school administration and students' families, and verbal permission was obtained from the students.

Peer-review: Internally peer reviewed.

\section{Authorship Contributions}

Concept: E.U.A., M.S.Y., T.H., N.B., H.Ö., Design: S.Ü., E.U.A., M.S.Y., T.H., N.B., H.Ö., Data Collection or Processing: E.U.A., M.S.Y., T.H., N.B., H.Ö., Analysis or Interpretation: S.Ü., Ö.A., H.K.Ü., Literature

Search: A.G., S.Ü., Writing: A.G., S.Ü.

Conflict of Interest: No conflict of interest was declared by theauthors.

Financial Disclosure: The authors declared that this studyreceived no financial support.

\section{References}

1. Alpözgen AZ, Özdinçler AR. Fiziksel aktivite ve koruyucu etkileri: Derleme. HSP 2016;3:66-72.

2. Camacho TC, Roberts RE, Lazarus NB, Kaplan GA, Cohen RD. Physical activity and depression: evidence from the alameda county study. Am J Epidemiol 1991;134:220-31.

3. Kubota Y, Evenson KR, MacLehose RF, Roetker NS, Joshu CE, Folsom AR. Physical activity and lifetime risk of cardiovascular disease and cancer. Med Sci Sports Exerc 2017;49:1599-605.

4. Schmalz DL, Deane GD, Birch LL, Krahnstoever Davison K. A longitudinal assessment of the links between physival activity and self esteem in early adolescent non-hispanic females. J Adolesc Health 2007;41:559-65.

5. Crane JR, Naylor PJ, Temple VA. The physical activity and sedentary behaviour patterns of children in kindergarten and grade 2. Children (Basel) 2018;5:131.

6. Efrat MW. Exploring strategies that influence children's physical activity self-efficacy. CIER 2017;10:87.

7. Özen T. Exercise self efficacy scale’ın (egzersiz öz yeterlilik ölçeği) ankilozan spondilitli hastalarda Türkçe geçerlilik-güvenilirliği ve diğer faktörlerle ilişkisi. Yüksek Lisans Tezi: Trakya Üniversitesi. 2016.

8. Aypay A. The Adaptation Study of General Self-Efficacy (GSE) Scale to Turkish. İnönü Üni Eğt Fak Derg 2010;11:113-31.

9. Campbell NJ. The measurement of physical activity and self-efficacy in adolescents: Prospects, problems, and future directions. Electronic Thesis and Dissertation Repository: Western University. Available from: URL: https://ir.lib.uwo.ca/etd/599

10. Liu H, Dai X. Correlation between physical activity and self-efficacy in Chinese university students. J Sport Psychol 2017;26:110-4.

11. Cataldo R, John J, Chandran L, Pati S, Shroyer ALW. Impact of physical activity intervention programs on self-efficacy in youths: A systematic review. ISRN Obesity 2013;1-11.

12. Cengiz C, İnce ML. Farklı okul ortamlarındaki çocukların okul sonrası fiziksel aktivitelerde algıladıkları öz-yeterlikleri. Yönetim Bilimleri Derg 2013;11:135-47.

13. Dzewaltowski DA, Geller KS, Rosenkranz RR, Karteroliotis K. Children's self-efficacy and proxy efficacy for after-school physical activity. Psychol Sport Exerc 2010;11:100-6.

14. Manley, DM. Self-efficacy, physical activity, and aerobic fitness in middle school children: Examination of a pedometer intervention program. Theses and Dissertations (ETD): University of Tennessee Health Science Center. 2008. doi: 10.21007/etd.cghs.2008.0198.

15. Wu TY, Robbins LB, Hsieh HF. Instrument development and validation of perceived physical activity self-efficacy scale for adolescents. Res Theory Nurs Pract 2011;25:39-54.

16. Tanır H. İlköğretim 8. sınıf öğrencilerinde fiziksel aktivite düzeyi ve bazı antropometrik özelliklerin akademik başarı ile ilişkisi. Doktora Tezi: Kırıkkale Üniversitesi. 2013.

17. Emlek Sert Z, Bayık Temel A. İlköğretim öğrencileri için fiziksel aktivite soru formunun Türk toplumuna uyarlanması: geçerlilik ve güvenilirlik çalışması. DEUHYO ED 2014;7:109-14.

18. Saunders RP, Pate RR, Felton G, Dowda M, Weinrich MC, Ward DS, et al. Development of questionnaires to measure psychosocial influences on children's physical activity. Prev Med 1997;26:241-7.

19. Sherwood NE, Taylor WC, Treuth M, Klesges LM, Baranowski T, Zhou A, et al. Measurement characteristics of activity-related psychosocial measures in 8- to 10-year-old African-American girls in the Girls Health Enrichment Multisite Study (GEMS). Prev Med 2004;38:S60-8.

20. Moreno LA, Pigeot I, Ahrens W. Epidemiology of obesity in children and adolescents: prevalence and etiology. New York, NY: Springer; 2011. 
21. Yüceşahin MM, Tuysuz S. Patterns of urban socio-spatial differentiation in Ankara: An empirical analysis. J Geogr Sci 2011;9:159-88.

22. Seçer İ. SPSS ve Lisrel ile pratik veri analizi. 2. Baskı. Ankara: Anı Yayıncılık; 2015.

23. İlhan M, Çetin B. LISREL ve AMOS programları kullanılarak gerçekleştirilen yapısal eşitlik modeli (YEM) analizlerine ilişkin sonuçların karşılaştırılması. EPOD 2014;5:26-42.

24. Kılıç S. Cronbach'ın alfa güvenirlik katsayısı. JMOOD 2016;6:47-8.

25. Türk Ç, Karataş H, Bektaş M. Tip 1 diyabetli adölesanlarda diyabet bakımında ebeveyn izlemi ölçeğinin geçerlik ve güvenirlik çalışması. J Pediat Res 2016;3:35-40.

26. Saygın Ö, Göral K, Bingöl E, Ceylan Hİ. Fiziksel aktivite yeterliği ölçeğinin Türkçeye uyarlanması: Geçerlik ve güvenirlik çalışması. USEABD 2017;3:44-54.

27. Savaşhan Ç, Sarı O, Aydoğan Ü, Erdal M. İlkokul çağındaki çocuklarda obezite görülme sıklığı ve risk faktörleri. TAHUD 2015;19:14-21.

28. Orhan R. Çocuk gelişiminde fiziksel aktivite ve sporun önemi. KÜSBD 2019;9:157-76.

29. Helmerhorst HJF, Brage S, Warren J, Besson H, Ekelund U. A systematic review of reliability and objective criterion-related validity of physical activity questionnaire. Int J Behav Nutr and Phys Act 2012;9:103.

30. Huang WY, Wong SHS, Salmon J. Reliability and validity of the modified Chinese version of the children's leisure activities study survey (class) questionnaire in assessing physical activity among hong kong children. Pediatr Exerc Sci 2009;21:339-53.

31. Mciza ZJ, Goedecke JH, Lambert EV. Validity and reliability of a physical activity/inactivity questionnaire in South African primary schoolgirls. SAJSM 2007;19:117-24.
32. Perry CM, De Ayala RJ, Lebow R, Hayden E. A Validation and Reliability Study of the Physical Activity and Healthy Food Efficacy Scale for Children (PAHFE). Health Educ Behav 2008;35:346-60.

33. Crocker PR, Bailey DA, Faulkner RA, Kowalski KC, Mcgrath R. Measuring general levels of physical activity: preliminary evidence for the Physical Activity Questionnaire for Older Children. Med Sci Sports Exerc 1997;29:1344-9.

34. Kowalski K, Crocker P, Donen R. The Physical Activity Questionnaire for Older Children (PAQ-C) and Adolescents (PAQ-A) Manual. Canada: College of Kinesiology, University of Saskatchewan. 2004.

35. Korkmaz N. Bel ağrılı hastalarda izokinetik egzersiz programının korku kaçınma tutumları üzerine etkisi. Uzmanlık Tezi: Hacettepe Üniversitesi. 2006.

36. Ercan İ, Kan İ. Ölçeklerde güvenirlik ve geçerlik. UÜTFD 2004;30:211-6.

37. Çankırı B. Çocuk- ergen alay edilme ölçeği' nin Türkçeye uyarlanması, geçerlik ve güvenirliğinin incelenmesi. Yüksek Lisans Tezi: İzmir Katip Çelebi Üniversitesi. 2016.

38. Altıparmak D, Arslan FT. Aile merkezli bakım ölçeği'nin Türkçe’ye uyarlanması geçerlik ve güvenirlik çalışması. J Pediatr Res 2016;3:97103.

39. Durmuş B, Yurtkoru ES, Çinko M. Sosyal bilimlerde SPSS'le veri analizi. 5. Baskı. İstanbul: Beta Yayınevi; 2013.

40. Hair JF, Black WC, Babin BJ, Anderson RE. Multivariate Data Analysis. Seventh Edition. London: Pearson Education Limited; 2014 .

41. Çakmur H. Araştırmalarda ölçme-güvenilirlik-geçerlilik. TAF Prev Med Bull 2012;11:339-44.

42. Çapık C. Geçerlilik ve güvenirlik çalışmalarında doğrulayıcı faktör analizinin kullanımı. J Anatolia Nurs Health Sci 2014;17:196-205.

43. Aytaç M, Öngen B. Doğrulayıcı faktör analizi ile yeni çevresel paradigma ölçeğinin yapı geçerliliğinin incelenmesi. İstatistikçiler Dergisi 2012;5:14-22.

\section{APPENDIX 1. Physical Activity Self-efficacy scale for children in Turkish}

Below are some situations about how hard it can be to be physically active and more physically active. Check the option (not at all difficult, somewhat difficult or very difficult) that best expresses how difficult each sentence is for you.

\section{How hard do you think it is to do the following?}

1. Being physically active instead of watching TV

\section{Being physically active after school most days of the week}

3. Asking my family or other elders to do things that require physical activity with me

\section{Asking my family or other elders to take me to physical activity or sports}

5. Asking my friends to do physical activity with me.

6. Being physically active on weekends (saturday and sunday)

7. Playing in sports teams

8. Being physically active at home

9. Being physically active even when tired

Evaluation: There is no reverse-coded item in the scale. While scoring; not at all difficult $=1$ point, slightly difficult $=2$ points, very difficult $=3$ points. Scale total score is calculated by adding the scores obtained from all items. The lowest score that can be obtained from the scale is 9 , the highest score is 27 . High scores from the scale indicate the strength of self-efficacy for physical activity 